TREE-RING RESEARCH, Vol. 60(1), 2004, pp. 3-13

\title{
CLIMATE-GROWTH RELATIONSHIPS FOR NATIVE AND NONNATIVE PINACEAE IN NORTHERN MICHIGAN'S PINE BARRENS
}

\author{
W. J. Beal Botanical Garden \\ Department of Plant Biology \\ Michigan State University \\ East Lansing, MI 48824
}

JASON S. KILGORE* and FRANK W. TELEWSKI

\begin{abstract}
Secondary growth responses of native and nonnative trees exposed to the same climatic conditions can elucidate sensitivities and thus adaptability to a particular region. A long-term mixed-species planting in the pine barrens of northern lower Michigan presented an opportunity to discriminate responses from species commonly planted in this region. Mean ring-width chronologies from living native Pinus resinosa Ait. and P. strobus L. and nonnative P. sylvestris L. and Picea abies (L.) Karst. at this plantation were generated, standardized, and analyzed by correlation analysis against mean monthly climatic variables. The native pine chronologies had the highest mean ring widths and signal-to-noise ratios (SNR), were highly correlated to each other, and exhibited positive responses to years with above-normal April temperatures but no significant relationships to variations in precipitation. The P. sylvestris chronology was highly correlated to the other two pine chronologies and responded similarly to April temperatures but exhibited negative correlations to January and April precipitation and positive correlations to September precipitation. The $P$. abies chronology had the highest mean sensitivity and was correlated with the $P$. strobus chronology but only responded positively to precipitation from the previous December. The low SNR ( $P$. sylvestris, $P$. abies), high mean sensitivity ( $P$. abies), and larger number of significant correlations to variations in monthly climatic variables ( $P$. sylvestris) suggest that these nonnative species are more sensitive to this local climate. These results provide insights to the adaptability, establishment, and geographic distribution of the nonnative Pinaceae.
\end{abstract}

Keywords: growth response, native, exotic, pine barrens, dendroecology, Michigan.

\section{INTRODUCTION}

The response of a species to the spatial and temporal variation in resources, as a function of the physical environment, natural enemies, and competitors, is fundamental to its success in a given community (Shea and Chasson 2002). This approach to understanding niche opportunities (Shea and Chesson 2002) provides an avenue for investigating the ability of nonnative species to establish and possibly even invade native communities. Response to climatic variation is traditionally considered a primary determinant of biogeographical range for a particular species. Although the mean climate regulates species establishment and survival, the extreme climatic events (Cook et al. 1987),

\footnotetext{
*Corresponding Author: kilgorej@msu.edu.
}

such as early and late-season frosts, extreme winter temperatures, and droughts, affect growth and success in regeneration and therefore restrict the long-term species pool (Woodward 1987). Given species with similar ecological tolerances and function but different native biogeographical ranges, those species that are best able to exploit the available resources will be most successful when grown together. This has important implications to assessing the ability of a nonnative species to grow and ultimately invade, via successful regeneration, a community dominated by native species with similar fundamental niches. Dendrochronology provides a useful tool to measure the tree's ability to take advantage of local resources. The limiting climatic factors to growth (Fritts 1966, 1976; La Marche 1978; Fritts and Swetnam 1989) for a tree species provide information for assessing the suit- 
ability of that species to its particular environment and also provide baseline climatic response information for longer-term climatic change studies (e.g. Fritts 1991).

Following the 19th Century wildfires in the pine barrens of northern Michigan, native Pinus resinosa, $P$. strobus, and $P$. banksiana Lamb. and nonnative $P$. sylvestris were planted extensively and the nonnative Picea abies was planted intermittently. Many of these plantations are now being harvested, but many stands of the nonnative Pinaceae remain. All of these species share a similar fundamental niche (Burns and Honkala 1990). Because both Picea abies and Pinus sylvestris are capable of regenerating naturally in this ecosystem (Kilgore 2002), these nonnative species may be invasive under particular conditions. Consequently, investigating their dendrochronological response to the current climate regime will provide a baseline for assessing reactions to climate change and will lead to greater predictability of their potential for long-term establishment. All of the species are expected to express sensitivity in their radial growth in response to the droughty, infertile soil and cold continental climate in the region (Whitney 1986), but particular sensitivities may indicate climatic limitations to geographic range for the nonnative species.

The purpose of this study is to assess the climatic sensitivity, or exploitation, by native and nonnative Pinaceae in northern Michigan's pine barrens through the influence of climate on radial growth. No other study has examined the climatic response for these species in the pine barren ecosystem of the Great Lakes region, and the use of climatic response information has not been used to assess potential for invasiveness in the Pinaceae. Because of the short growing season and limiting soil conditions, we predicted that radial growth for all species would be restricted by cool early and late growing season temperatures and dry summers. Although pine barrens fall within the ecological range for all of these species, we predicted that the native species would be more complacent to variations in climate because their seed source would more likely originate from a locally adapted population. A historically important plantation of Pinaceae located in the pine barrens of northern lower Michigan was studied to address these predictions.

\section{METHODS}

\section{Study Site}

The regional setting for this study was the pine barrens of the Midwest, which were formed upon the thick deposits of glacial outwash, largely composed of coarse soils, laid down 12000 years ago at the end of the Pleistocene glaciation (Whitney 1986; Werlein 1998). This region is now covered by at least second-growth upland pine forests and barrens growing on sandy soils interspersed with bogs and conifer swamps bordering former meltwater channels. The pine forests are dominated by Pinus strobus and $P$. resinosa, species whose native ranges overlap (Figure 1). The barrens are dominated by $P$. banksiana with scattered $P$. resinosa (Curtis 1971; Whitney 1986, 1987; Comer 1996). In addition to these native pines, the nonnative $P$. sylvestris has been planted in the pine barrens for timber and Christmas tree production (Burns and Honkala 1990), and the nonnative $P i$ cea abies is planted largely for windbreaks. The sandy soils of the barrens contain low nutrients, organic matter, and water-holding capacity (Mokma and Vance 1989).

The study site is the Grayling Beal Plantation (GBP) located southeast of the town of Grayling in Crawford County, Michigan $\left(44^{\circ} 39^{\prime} \mathrm{N}\right.$, $84^{\circ} 42^{\prime} \mathrm{W}, 346 \mathrm{~m}$ a.s.l.; Figure 1). In 1888-1889, seedlings, cuttings, and seed (Pinus rigida Mill. only) from 41 native and nonnative tree species were planted in a 5-acre (2.0 ha) sandy field to determine which species would grow best for reforestation and production (Beal 1888; Kilgore 2002). Prior to planting, the site experienced frequent fires leaving scattered $P$. resinosa and $P$. banksiana, scrubby Quercus spp., and dwarf Prunus spp. (Kedzie 1888), but no record or evidence of fire exists at this site since planting. The topography is level, and the homogenous soil (M. Kroell, personal communicaton) is mapped as a coarse, loose, strongly acidic, and excessively drained sand of the Grayling series (Typic, Frigid Udipsamment) (Mokma and Vance 1989; Werlein 1998). Although the depth to the water table was 


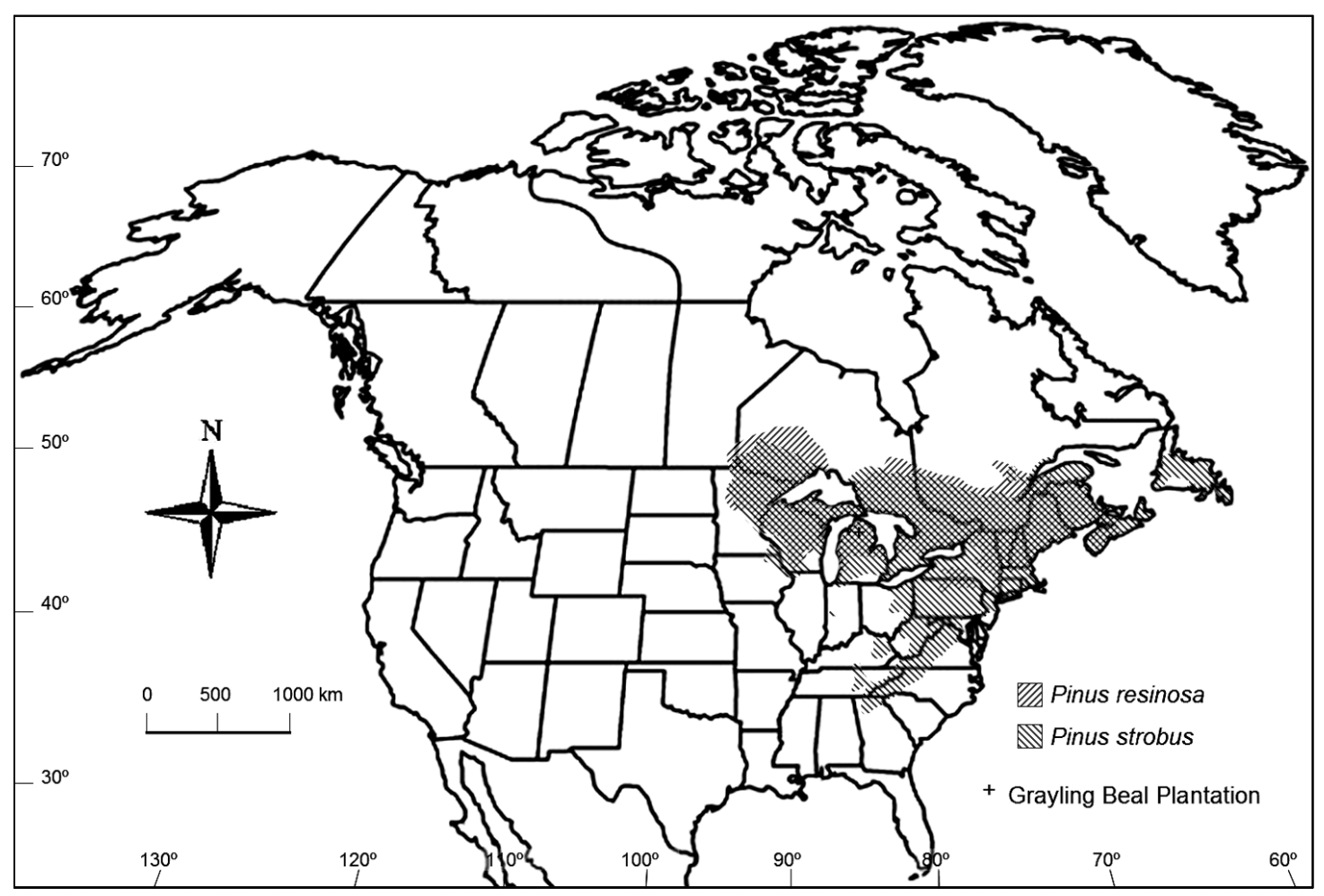

Figure 1. Map of North America showing the native distribution (redrawn from Little 1971) of Pinus resinosa and P. strobus and the Grayling Beal Plantation study site in northern lower Michigan.

not measured in this study, Werlein (1998) notes the water table to be $>6 \mathrm{ft}(1.83 \mathrm{~m})$ in this soil type. Government Land Office Survey records show that pre-European settlement forests on this soil type were largely composed of Pinus banksiana (Whitney 1986).

\section{Sample Collection and Data Analysis}

All of the surviving planted stems from the nonnative Picea abies, native Pinus resinosa, and native $P$. strobus and all of the large diameter regenerating stems from nonnative $P$. sylvestris were sampled to generate mean chronologies (Table 1); no other species, including $P$. banksiana that was not planted, had surviving or regenerating stems in sufficient numbers to analyze (Kilgore 2002). Trees were cored perpendicular to the stem lean to avoid reaction wood with $5.15-\mathrm{mm}$ diameter increment borers in 1998-2000. One full-diameter core or two opposite radial cores were obtained at approximately $0.3 \mathrm{~m}$ above the ground to obtain as many growth rings as possible. Increment cores were prepared, crossdated, and measured to 0.01 $\mathrm{mm}$ using standard dendrochronological techniques (Stokes and Smiley 1996). Ring-width measurements within each time series were computer-analyzed to detect anomalies (COFECHA Version 6.06P, Holmes 2000). Mean raw ring widths were compared across species using the conservative Tukey HSD Multiple Comparison procedure (Systat Version 9.01, SPSS Science, Inc. 1998), which allows comparisons among means with varying sample sizes (Sokal and Rohlf 1995).

All series of raw data were converted to mean chronologies for climate response analysis using the same program settings to ensure consistent comparisons among species and sites. Each series was detrended with a single-pass high-frequency filter, i.e. a negative exponential or negative linear regression was fit to the series (ARSTAN Version 6.04P, Holmes 2000). This conservative technique 
Table 1. Dendrochronological characteristics for the raw ring width data and ARSTAN (ARS) mean chronology for each of the Pinaceae at the Grayling Beal Plantation study site. All values calculated by ARSTAN (Holmes 2000).

\begin{tabular}{lcccc}
\hline \multicolumn{1}{c}{ Characteristics } & Picea abies & Pinus resinosa & Pinus strobus & Pinus sylvestris $^{-}$ \\
\hline No. trees & 11 & 22 & 10 & 10 \\
No. cores & 25 & 82 & 21 & 20 \\
Total years & 105 & 101 & 105 & 85 \\
Mean ring width (mm) & $1.788 \mathrm{~b}$ & $2.177 \mathrm{a}$ & $2.167 \mathrm{ab}$ & $1.896 \mathrm{ab}$ \\
SNR (detrended) $^{2}$ & 3.697 & 9.818 & 5.949 & 1.131 \\
\%PC1 (detrended) & 43.6 & 36.4 & 49.5 & 35.6 \\
Mean index (ARS) & 1.0063 & 1.0446 & 0.9863 & 0.9603 \\
Mean sensitivity (ARS) & 0.2569 & 0.1330 & 0.1810 & 0.1349 \\
Std. deviation (ARS) & 0.2511 & 0.3646 & 0.2232 & 0.2389 \\
Skewness (ARS) & -0.3041 & 2.1610 & -0.2052 & 0.4611 \\
Kurtosis (ARS) & 0.7971 & 6.8889 & 0.2696 & 0.9911 \\
Partial Autocorrelation (ARS) & & & & 0.7399 \\
$\quad$ 1st order & 0.1318 & 0.8021 & 0.5049 & -0.1707 \\
2nd order & -0.0623 & -0.0304 & -0.0121 & 0.0443 \\
3rd order & -0.1197 & -0.0765 & -0.1053 & 38 \\
Min sample size (no. trees) & & 13 & 6 & \\
\hline
\end{tabular}

${ }^{1}$ Mean ring width values with different letters across species are significantly different (Tukey HSD, $p<0.01$ ).

${ }^{2}$ Signal-to-noise ratio (SNR) based on detrended series.

${ }^{3}$ Percentage of variation accounted for by the first principal component of the correlation matrix of individual detrended series (Graumlich 1993).

${ }^{4}$ Minimum sample size based on a signal strength threshold of 0.85 (Briffa and Jones 1990).

should remove exogenous variation and the agerelated growth trend while retaining the climatically induced high-frequency variation (Fritts 1976; Cook et al. 1990). Of the three types of mean chronologies (STANDARD, RESID, and ARSTAN [ARSTAN Version 6.04P, Holmes 2000]) constructed from the detrended series, the ARSTAN chronology expresses the greatest sensitivity to climatic variations (Cook and Holmes 1997) and was thus used exclusively for the dendroclimatic analyses. Standard chronology statistics, such as signal-to-noise ratio (SNR), mean sensitivity (MS), partial autocorrelation coefficients, and the percentage of intraseries variation explained by the first principal component (\%PC1), were calculated by the program ARSTAN Version 6.04P (Holmes 2000). Because SNR is influenced by sample size, \%PC1 is a better measure of variance within each series and can be compared across chronologies (Graumlich 1993). Similar temporal response patterns among the ARSTAN chronologies constructed for each species were compared by simple correlation anal- ysis (Pearson correlation, Bonferroni probability, Systat Version 9.01, SPSS Science, Inc. 1998).

The relative importance of monthly precipitation and monthly mean temperature in influencing tree-ring growth for each species was determined by correlation and response function analysis (RESPO Version 6.06P, Holmes 2000). Correlation functions are the correlation coefficients between the climatic variables and mean chronologies, whereas the response function is a result of a multivariate regression analysis on a set of principal components (PCs) calculated from climatic variables (Fritts 1976). PCs enter the stepwise regression if the cumulative multiple of eigenvalue is greater than one, thus the number of PCs retained varies by chronology (RESPO Version 6.06P, Holmes 2000). Although response function analysis has been shown to be highly effective at showing relationships between climate and growth (Fritts and Wu 1986), the response function can be more difficult to replicate and interpret (Blasing et al. 1984). Caution must be given regarding the interpretation of the direction of correlation coeffi- 


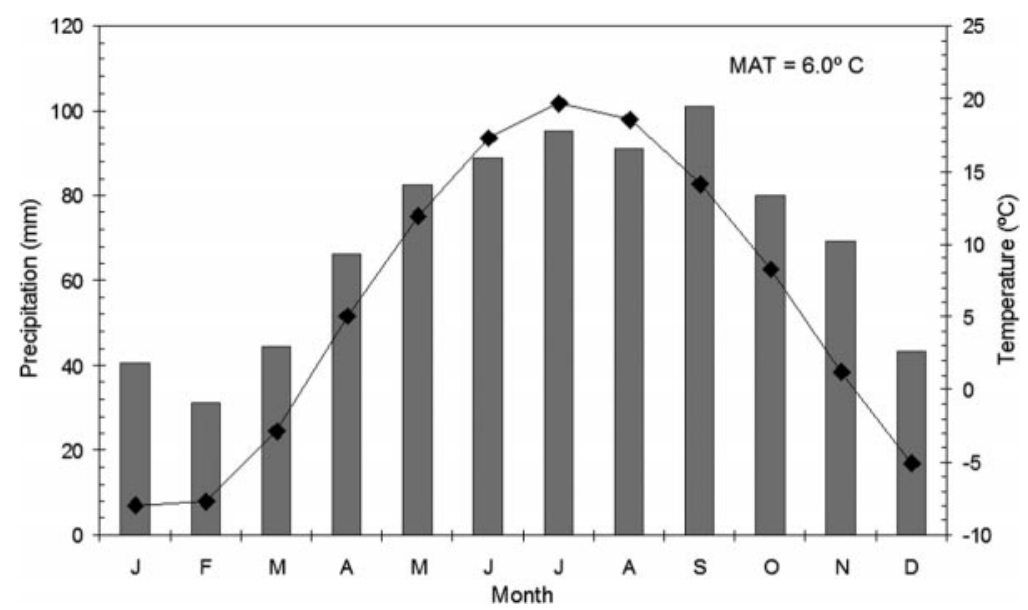

Figure 2. Climograph for Grayling, Michigan $\left(44^{\circ} 39^{\prime} \mathrm{N}, 84^{\circ} 42^{\prime} \mathrm{W}, 346.3 \mathrm{~m}\right.$ a.s.1., records from 1931-1998, COOP ID 203391, National Climatic Data Center 2001). Bars indicate mean total monthly precipitation (mm), and solid line indicates mean monthly temperature $\left({ }^{\circ} \mathrm{C}\right)$. MTAP is the mean total annual precipitation, and MAT is the mean annual temperature.

cients or weights, in the case of response functions, because either a wider or narrower ring could be associated with an abnormally high or low climate parameter. Because the pattern of the response functions was similar to the correlation functions, only the results of the correlation functions are considered in this paper.

For the dendroclimatic analysis, the predictand was each ARSTAN chronology, and the predictors were 15 sequential months (previous July through current September) of total precipitation and mean temperature variables from the time of earliest recording (1931) to most recent ring formation (1998). Data were obtained from the climate data station located approximately $2 \mathrm{~km}$ to the northwest in Grayling (National Climatic Data Center 2001). The mean annual precipitation for this period was $833 \mathrm{~mm}$ with $63 \%$ of the precipitation falling during April-September (Figure 2). The mean annual temperature was $6.0^{\circ} \mathrm{C}$, and the mean April-September temperature was $14.4^{\circ} \mathrm{C}$. The growing season is generally cool and short with only 2068 growing degree days and a frostfree growing season of 110 days (Werlein 1998). A post-hoc correlation of March-April mean monthly snowfall and maximum snow depth (National Climatic Data Center 2001) against the STANDARD chronologies to determine if late winter snowfall or snowpack were related to radial growth yielded no significant $(\mathrm{p}<0.05)$ relationships.

\section{RESULTS}

Site master chronologies (Figure 3) were constructed for four species based on standardized ring-width data summarized in Table 1. The GBP site yielded four master chronologies of 105 years for Picea abies and Pinus strobus, 101 years for $P$. resinosa, and 85 years for the regenerating $P$. sylvestris. Based on a signal strength threshold of 0.85 (Briffa and Jones 1990), P. sylvestris was the only species that would have required additional samples to fully replicate the chronologies from a subsample. The mean ring widths for the native pines were larger than for the nonnative Pinaceae. The SNR, a measure of variance common within detrended series (Graumlich 1993), varied by species but was more a reflection of sample size (Briffa and Jones 1990). The more reliable measure of series signal strength, \% $\mathrm{PC} 1$, was highest for $P$. strobus and Picea abies, followed by Pinus resinosa and $P$. sylvestris. Mean sensitivity (MS) was highest for Picea abies followed by Pinus strobus, while $P$. resinosa and $P$. sylvestris expressed the least high-frequency variance. The amount of lowfrequency variance as expressed by the standard deviation of the autoregressively modeled chro- 

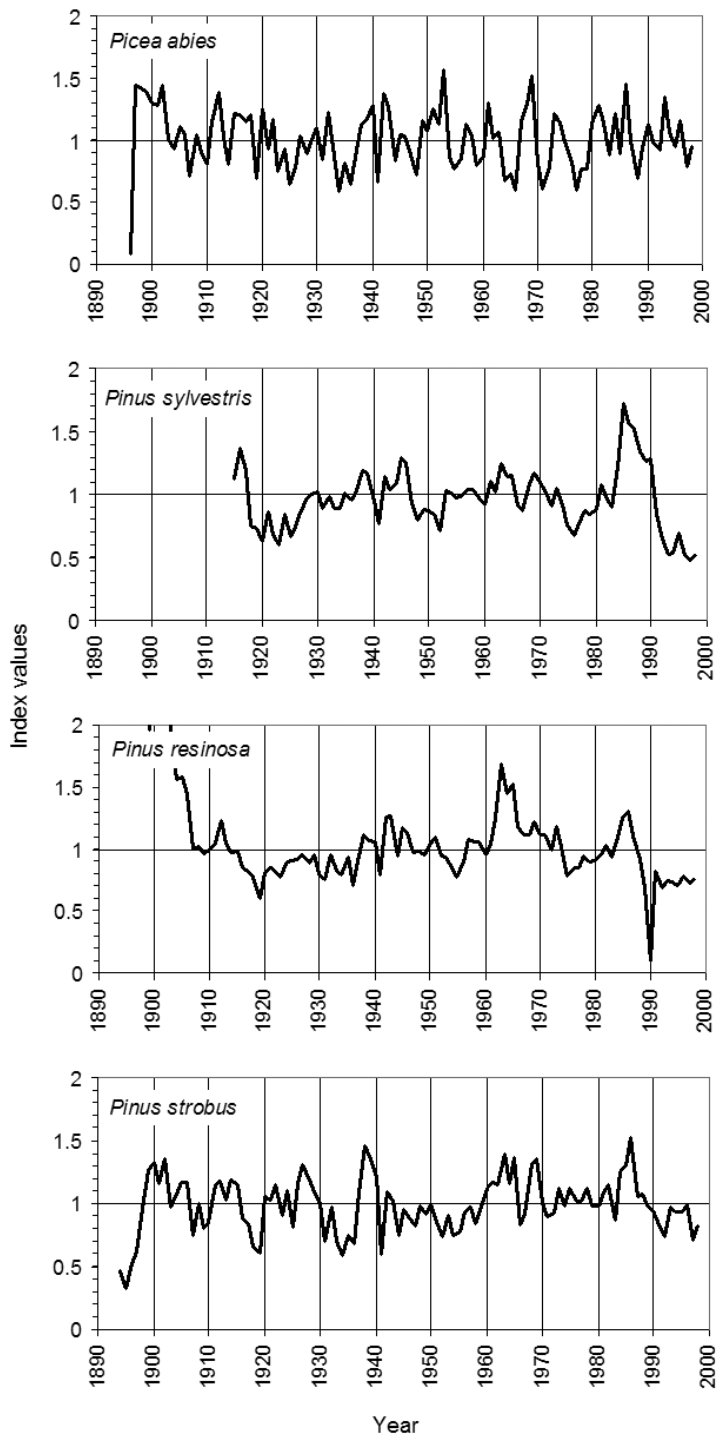

Figure 3. ARSTAN ring-width chronologies constructed for the nonnative (Picea abies and Pinus sylvestris) and native ( $P$. strobus and P. resinosa) conifers at the Grayling Beal Plantation study site.

nology (Graumlich 1993) was highest for P. resinosa. This chronology also retained the largest first-order autocorrelation coefficient, suggesting that some low-frequency variance remains in the standardized chronology. However, the chronology for Picea abies retained little low-frequency variance even at the first-order for autocorrelation. When compared across species, the ARSTAN chronologies for the pines were significantly $(\mathrm{p}<$
0.001) correlated, but only the Pinus strobus chronology was significantly $(\mathrm{p}<0.001)$ correlated to the Picea abies chronology (Table 2).

Mean monthly temperature and monthly precipitation explained 40.2, 33.8, 28.4, and $46.8 \%$ of the variation in the ARSTAN chronologies for $P i$ cea abies, Pinus resinosa, $P$. strobus, and $P$. sylvestris, respectively. Significant responses (Table 3 ) by the nonnative Picea abies were limited to a positive correlation $(r=0.28, p<0.05)$ to December temperatures of the previous growing season (Figure 4). Similarly, the native $P$. strobus and $P$. resinosa exhibited positive associations $(\mathrm{r}=$ 0.26 and $\mathrm{r}=0.24, \mathrm{p}<0.05)$ with April temperatures but expressed no other significant response to variations in temperature or precipitation (Figure 5). The other nonnnative, $P$. sylvestris, responded positively to April temperatures $(\mathrm{r}=$ 0.31, $\mathrm{p}<0.05)$ and September precipitation $(\mathrm{r}=$ $0.25, \mathrm{p}<0.05)$ but negatively to January $(\mathrm{r}=$ $-0.34, \mathrm{p}<0.05)$ and April $(\mathrm{r}=-0.29, \mathrm{p}<0.05)$ precipitation.

\section{DISCUSSION}

A notably small number of trees were required to generate each chronology with the exception of Pinus sylvestris (Table 1), and thus allowed a smaller sample size to represent the response of each species (Briffa and Jones 1990). This indicates that inclusion of additional trees would not have significantly improved the chronology signal or altered the interpretation. The Pinaceae that are native to less xeric environments appear to be less adapted to short-term fluctuations in the climate regime at this site. Mean sensitivity (MS), an indication of the degree to which radial growth varies from year to year (Fritts 1976), and $\%$ PC1 were highest for Picea abies and Pinus strobus (Table 1), species that prefer more mesic soil conditions than the other Pinaceae growing at GBP (Whitney 1986; Schweingruber 1993; MacDonald et al. 1998). In addition, the chronologies for Picea abies and Pinus strobus exhibit lower first-order autocorrelation coefficients than the other species (Table 1), indicating lower persistence in growth in successive years. Working in the mixed conifer-hardwood forests of the western 
Table 2. Pearson correlation coefficients $(r)$ and significance (Bonferroni probability) between the ARSTAN master chronologies developed for each species at the Grayling Beal Plantation study site. All values calculated by Systat Version 9.01 (SPSS Science, Inc. 1998).

\begin{tabular}{lcccc}
\hline & Picea abies & Pinus resinosa & Pinus strobus & Pinus sylvestris \\
\hline Picea abies & 1.000 & & & \\
Pinus resinosa & 0.234 & 1.000 & & \\
Pinus strobus & $0.408^{* * *}$ & $0.594^{* * * *}$ & 1.000 & 1.000 \\
Pinus sylvestris & 0.313 & $0.583^{* * * *}$ & $0.429^{* * *}$ & \\
\hline
\end{tabular}

$* \mathrm{p}<0.05, * * \mathrm{p}<0.01, * * * \mathrm{p}<0.001, * * * * \mathrm{p}<0.0001$.

Great Lakes, Graumlich (1993) found similar results for $P$. strobus ( $\mathrm{MS}=0.18, \% \mathrm{PC} 1=46.3$ ) and $P$. resinosa $(\mathrm{MS}=0.16, \% \mathrm{PC} 1=33.9)$. Data collected by Fritts (DeWitt and Ames 1978) for $P$. resinosa in northern Minnesota indicated similar mean sensitivities $(0.18,0.11$, and 0.21$)$. A study by Koop (1985) of old-growth $P$. resinosa growing at a dry mesic site (Hartwick Pines State Park, HRP) approximately $10 \mathrm{~km}$ north of GBP found a mean sensitivity (ARSTAN chronology) of 0.15 . Because radial growth is affected by climate (Fritts 1976), higher mean sensitivity gives an indication of the strength of dependence on a limiting factor(s) having high-frequency variance, presumably climate. Consequently, allocation to secondary radial growth in Picea abies appears to be more sensitive to available resources and subsequent photosynthate supply in the short-term at this location than for the other species.

The chronologies for the native Pinus strobus and $P$. resinosa were significantly correlated to variations in April temperatures but showed no significant relationships to any other climatic variable examined in this study. Because of their evergreen foliage and large earlywood xylem, coni- fers are able to take advantage of warm temperatures early in the growing season, thus a larger growth ring is formed (Fritts 1976). Koop (1985) examined only the current year's climatic parameters with a $P$. resinosa chronology (RESID): April $(\mathrm{r}=0.22, \mathrm{p}<0.05)$, June $(\mathrm{r}=-0.34, \mathrm{p}$ $<0.005$ ), and July ( $\mathrm{r}=-0.29, \mathrm{p}<0.05)$ temperatures and June precipitation $(\mathrm{r}=0.218, \mathrm{p}<$ $0.05)$ were significant. The difference in Summer precipitation responses could be attributable to the use of a different number of climatic parameters in the analysis. Furthermore, although GBP is a relatively even-aged closed canopy forest on level ground, the crowns of the uneven-aged trees at HRP are more exposed to solar radiation and wind, and the roots are presumably further from the soil water because they grow along a ridge (Koop 1985). Consequently, these trees may suffer greater water stress through evaporative water loss and have less access to soil water than those trees at GBP. In addition, the pines at HRP are larger and older, and thus have a greater overall respiratory demand and are less physiologically robust (Kozlowski 1971). A differential response to variation in temperature and precipitation would thus be ex-

Table 3. Significant $(\mathrm{p}<0.05)$ correlations between ARSTAN master chronologies and monthly climate variables at the Grayling Beal Plantation study site. All values calculated by RESPO Version 6.06P (Holmes 2000).

\begin{tabular}{lrl}
\hline \multicolumn{1}{c}{ Species } & Correlation & \multicolumn{1}{c}{ Variable } \\
\hline Picea abies & 0.2777 & Total prior December precipitation \\
Pinus resinosa & 0.2392 & Mean April temperature \\
Pinus strobus & 0.2570 & Mean April temperature \\
Pinus sylvestris & 0.3113 & Mean April temperature \\
& -0.3403 & Total January precipitation \\
& -0.2970 & Total April precipitation \\
& 0.2519 & Total September precipitation \\
\hline
\end{tabular}




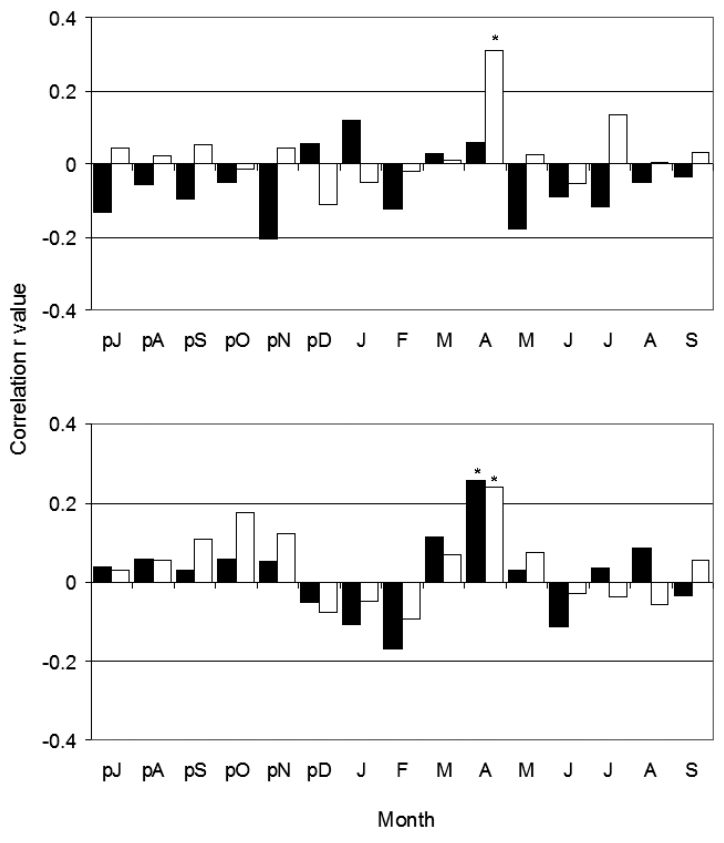

Figure 4. Correlation functions for the ARSTAN chronologies of Picea abies (6 trees, 25 series), Pinus sylvestris (5 trees, 20 series), Pinus strobus (10 trees, 21 series), and P. resinosa (23 trees, 82 series) against the mean monthly temperature for the previous ( $\mathrm{p}$ ) and current growing seasons at the Grayling Beal Plantation study site. Significant $(\mathrm{p}<0.05)$ responses to a climatic variable are denoted by $*$.

pected across the two sites. However, except in extremely dry soils, Pinus resinosa appears to be insensitive to precipitation but may be restricted by warming temperatures (Pan and Raynal 1995).

The population size of mature Pinus sylvestris at GBP did not meet the signal strength threshold suggested by Briffa and Jones (1990), and thus a larger sample size (Table 1) would be needed for a more accurate interpretation of this species' response. Unfortunately, we were unable to locate any stands of $P$. sylvestris of similar or older age in the jack pine barrens. Nevertheless, the results obtained from this population serve as an initial view into how this nonnative conifer responds to its environment. Despite a low mean sensitivity, the $P$. sylvestris responded more to variations in precipitation than any other species considered (Figure 5). Increased radial growth was associated with higher late-season precipitation, suggesting that $P$. sylvestris has a longer phenology of cambial activity than the other Pinaceae, thereby in-

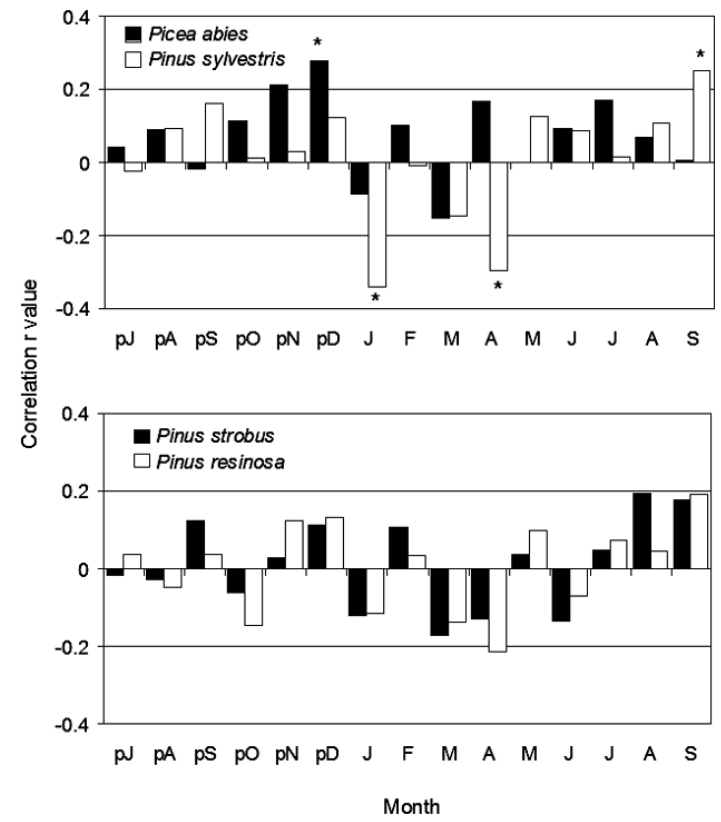

Figure 5. Correlation functions for the ARSTAN chronologies of Picea abies (6 trees, 25 series), Pinus sylvestris (5 trees, 20 series), Pinus strobus (10 trees, 21 series), and P. resinosa (23 trees, 82 series) against the monthly precipitation for the previous (p) and current growing seasons at the Grayling Beal Plantation study site. Significant $(\mathrm{p}<0.05)$ responses to a climatic variable are denoted by $*$.

creasing production of photosynthates at the end of the growing season in these years more efficiently than the other species. Abnormally high precipitation during the growing season is expected to provide more available water for cambial cell expansion (Fritts 1976) resulting in greater radial growth. However, although the native pines expressed negative associations of radial growth with January and April precipitation, these correlations are significant only for P. sylvestris. Abnormally high snowfall in January (e.g. 1979) may maintain low soil temperatures through early Spring (Thomsen 2001), thus delaying bud break, leaf expansion, and cambial induction and reducing radial growth for the year. The negative April relationship may be better explained by less influx of solar radiation caused by clouded skies than by water availability (Fritts 1976), especially considering the strong positive correlation to April temperature; unfortunately, the requisite climate data for that analysis are not available. Thus, $P$. sylvestris 
could be taking advantage of the local resources, including climate, by extending its phenology, resulting in greater biomass accumulation, or is closer to the center of its ecological range than the two native pines (Figure 1). If $P$. sylvestris is more adapted than the native pines to the local environment, as has been observed by others in North America (Pan and Raynal 1995), then the application of dendrochronological techniques may be useful in identifying the beneficial environmental factor that may be supporting the establishment and success of the species. However, the small sample size, low SNR, and low \%PC1 for this species necessitates concern over the interpretation of these results. In any case, the broad ecological distribution (Burns and Honkala 1990) of P. sylvestris and its potential ability to take advantage of local climate conditions supports the notion that $P$. sylvestris is at least a successful pioneer species (Gutierrez 1989).

The chronology for Picea abies expressed no relationship to variations in temperature, unlike the other Pinaceae, but a significant positive response to precipitation in the December preceding the growing season. Sensitivity in Picea abies to conditions during the previous growing season has been confirmed when growing within its native European range (Mäkinen et al. 2001) and to warmer winters in an Adirondack Mountain plantation (Pan and Raynal 1995). Although species living at the edge of their range express the greatest sensitivity to limiting factors like climate (Fritts 1976), the geographic range for $P$. abies includes much colder and more mesic environments (Schweingruber 1993) than Grayling; the physical features (e.g. short needles and fastigiate shape) of the $P$. abies at GBP resemble the more northern races of the species (Telewski, personal observation). As a result of this species' strong common variance $(\% \mathrm{PC} 1)$, relatively high MS, but low correlation to climatic variables during the growing season, the $P$. abies trees are neither limited by nor exploiting the climatic resources at this site.

\section{SUMMARY AND CONCLUSIONS}

The use of dendrochronological techniques to compare the high frequency radial growth re- sponse of native and nonnative species to climatic variables may elucidate ecological tolerances, or range limits, and consequently adaptability, in particular environments. Radial growth is more than a simple response to climate; the particular environmental conditions, including temperature, soil nutrients and available water, disturbances, pathogens, and insects, affect the ultimate product of annual xylem formation. When several species are planted and grown in a homogeneous environment, such as at the GBP, the exposure to restrictive growing conditions is approximately uniform. Furthermore, pines have been shown to have greater species-specific responses across different growing conditions than interspecific variation within a climate regime (Graumlich 1993). Consequently, comparisons of growth responses across species at one location are legitimate. Unfortunately, few have investigated the dendroclimatic responses for these species in North America, especially in the Great Lakes region. Comparisons of the results from this study to other studies are accordingly limited.

In this study, the nonnative Pinus sylvestris and Picea abies demonstrated more differential response to climatic variations than did the native Pinus resinosa and $P$. strobus. By extending its phenology in years of exceptional climatic resources, $P$. sylvestris may be gaining advantage in its growth in the pine barrens ecosystem. Picea abies does not appear to be affected by any variations in growing season climate yet is highly sensitive to current year's photosynthate production. Examining these climatic relationships for these species at other pine barren sites should support the application of dendrochronology in the field of invasion ecology.

\section{ACKNOWLEDGMENTS}

The authors appreciate the field assistance from Pam Kilgore, Robyn Ast, Steve Nimcheski, Steve Lettero, Denise Kemp, and Alex Zörnig. Chris Baisan, Rex Adams, Tom Harlan, and Harold Fritts kindly spent time discussing this project with the authors, and Marty Kroell provided soil information. We also thank Steven Leavitt, Yves Begin, and two anonymous reviewers for com- 
ments that greatly improved earlier versions of this manuscript. This research was supported by a grant from Sigma Xi (The Scientific Research Society), with logistical support provided by the Division of Campus Park and Planning at Michigan State University.

\section{REFERENCES CITED}

Beal, W. J.

1888 Report of the Botanist of the Experiment Station. In Twenty-Seventh Annual Report of the Secretary of the State Board of Agriculture of the State of Michigan, 1888, Thorp and Godfrey, State Printers and Binders, Lansing; pp. 171-193.

Blasing, T. J., A. M. Solomon, and D. N. Duvick

1984 Response functions revisited. Tree-Ring Bulletin 44: $1-15$.

Briffa, K., and P. D. Jones

1990 Basic chronology statistics and assessment. In Methods of Dendrochronology: Applications in the Environmental Sciences, edited by E. R. Cook and L. A. Kairiukstis, Kluwer Academic Publishers, Dordrecht; pp. 137-152.

Burns, R. M., and B. H. Honkala

1990 Silvics of North America: 1. Conifers. Agricultural Handbook 654. US Department of Agriculture, Forest Service, Washington, D.C.

Comer, P. J.

1996 Natural Community Abstract for Pine Barrens. Michigan Natural Features Inventory, Lansing.

Cook, E. R., A. H. Johnson, and T. J. Blasing

1987 Forest decline: modeling the effect of climate in tree rings. Tree Physiology 3:27-40.

Cook, E. R., K. R. Briffa, S. G. Shiyatov, and V. Mazepa

1990 Tree-ring standardization and growth-trend estimation. In Methods of Dendrochronology: Applications in the Environmental Sciences, edited by E. R. Cook and L. A. Kairiukstis, Kluwer Academic Publishers, Dordrecht; pp. 104-123.

Cook, E. R., and R. L. Holmes

1997 ARSTAN: chronology development. In Documentation to the International Tree-Ring Data Bank Program Library Version 2.1, edited by H. D. GrissinoMayer, R. L. Holmes, and H. C. Fritts, URL: http:// tree.ltrr.arizona.edu/software.html; pp. 75-87.

Curtis, J. T.

1971 The Vegetation of Wisconsin: An Ordination of Plant Communities. University of Wisconsin Press, Madison.

DeWitt, E., and M. Ames, Editors

1978 Tree-Ring Chronologies of Eastern North America. The University of Arizona, Tucson.

Fritts, H. C.

1966 Growth rings of trees: Their correlation with climate. Science 154:973-979.
Fritts, H. C.

1976 Tree Rings and Climate. Academic Press, New York. Fritts, H.C.

1991 Reconstructing Large-Scale Climatic Patterns from Tree-Ring Data. The University of Arizona Press, Tucson.

Fritts, H. C., and T. W. Swetnam

1989 Dendroecology: A tool for evaluating variations in past and present forest environments. Advances in Ecological Research 19:111-188.

Fritts, H. C., and X. Wu

1986 A comparison between response-function analysis and other techniques. Tree-Ring Bulletin 46:31-46.

Graumlich, L. J.

1993 Response of tree growth to climatic variation in the mixed conifer and deciduous forest of the Upper Great Lakes region. Canadian Journal of Forest Research 23:133-143.

Gutierrez, E.

1989 Dendroclimatological study of Pinus sylvestris L. in southern Catalonia (Spain). Tree-Ring Bulletin 46: $1-9$.

Holmes, R.

2000 Dendrochronology Program Library. URL: ftp:// ftp.cricyt.edu.ar/users/dendro/.

Kedzie, R. C.

1888 The jack pine plains, Bulletin No. 37-Chemical Department. In Twenty-Seventh Annual Report of the Secretary of the State Board of Agriculture of the State of Michigan, 1888, Thorp and Godfrey, State Printers and Binders, Lansing; pp. 207-211.

Kilgore, J. S

2002 An Historical and Dendroecological Analysis of a Long-term Reforestation Experiment in Grayling, Michigan. M.S. thesis, Michigan State University, East Lansing.

Koop, D. L.

1985 Reconstruction of Past Climate in Northern Lower Michigan Through the Analysis of Red Pine (Pinus resinosa Ait.) Tree Rings. M.S. thesis, University of Georgia, Athens.

Kozlowski, T. T.

1971 Growth and Development of Trees, Volume I: Seed Germination, Ontogeny, and Shoot Growth. Academic Press, New York.

La Marche, V. C, Jr.

1978 Tree-ring evidence of past climatic variability. Nature 276(5686):334-338.

Little, E. L., Jr.

1971 Atlas of United States Trees: Volume 1. Conifers and Important Hardwoods. Miscellaneous Publication 1146. US Department of Agriculture, Forest Service, Washington, D.C.

MacDonald, G. M., L. C. Cwynar, and C. Whitlock

1998 The late Quaternary dynamics of pines in northern North America. In The Ecology and Biogeography of Pinus, edited by D. M. Richardson, Cambridge University Press, Cambridge; pp. 122-136. 
Mäkinen, H., P. Nöjd, and K. Mielikäinen

2001 Climatic signal in annual growth variation in damaged and healthy stands of Norway spruce [Picea abies (L.) Karst.] in southern Finland. Trees 15:177185.

Mokma, D. L., and G. F. Vance

1989 Forest vegetation and origin of some spodic horizons, Michigan. Geoderma 43:311-324.

National Climatic Data Center

2001 Monthly climate data for Grayling (COOP ID 203391). U.S. Department of Commerce, National Oceanic and Atmospheric Administration, and $\mathrm{Na}-$ tional Environmental Satellite, Data and Information Service. URL: http://lwf.ncdc.noaa.gov/oa/ncdc.html.

Pan, Y., and D. J. Raynal

1995 Predicting growth of plantation conifers in the Adirondack Mountains in response to climate change. Canadian Journal of Forest Research 25:48-56.

Schweingruber, F. H.

1993 Trees and Wood in Dendrochronology: Morphological, Anatomical, and Tree-Ring Analytical Characteristics of Trees Frequently Used in Dendrochronology. Springer-Verlag, Berlin.

Shea, K., and P. Chesson

2002 Community ecology theory as a framework for biological invasions. TRENDS in Ecology and Evolution 17(4):170-176.
Sokal, R. R., and F. J. Rohlf

1995 Biometry, 3rd ed. W.H. Freeman and Company, New York.

SPSS Science, Inc.

1998 Systat Version 9.01. SPSS Science, Inc., Chicago.

Stokes, M., and T. Smiley

1996 An Introduction to Tree-Ring Dating. The University of Arizona Press, Tucson.

Thomsen, G.

2001 Response to winter precipitation in ring width chronologies of Pinus sylvestris L. from the northwestern Siberian Plain, Russia. Tree-Ring Research 57(1):1529.

Werlein, J. O.

1998 Soil Survey of Crawford County, Michigan. U.S. Department of Agriculture, Natural Resources Conservation Service, Washington, D.C.

Whitney, G. G.

1986 Relation of Michigan's presettlement pine forests to substrate and disturbance history. Ecology 67(6): $1548-1559$

Whitney, G. G.

1987 An ecological history of the Great Lakes forests of Michigan. Journal of Ecology 75:667-684.

Woodward, F. I.

1987 Climate and Plant Distribution. Cambridge University Press, Cambridge.

Received 23 September 2002; accepted 27 September 2003. 